\title{
Reflections on the APSA Congressional Fellowship from the Vantage Point of a Non-Academic Career
}

\author{
Daniel Stid, Hewlett Foundation
}

\section{M} y experience as a congressional fellow has had a profound impact on the course of my career. I came to Washington in the fall of 1995 as an assistant professor hoping to parlay the fellowship experience into a new research program. I lucked into a placement that set me up perfectly for this goal. In retrospect, I learned more during my fellowship than I have in any other year of my career. Yetparadoxically-the intellectual and professional momentum I gained during my fellowship propelled me out of the academy and into the fields of management consulting, nonprofits, and philanthropy, where I have worked ever since. This might seem like a missed opportunity, insofar I left the study of Congress behind. In fact, the opportunity has been fully realized over the years, albeit in a roundabout way.

But I should back up and share how my fellowship unfolded. Reading the accounts of more recent fellows in this symposium, I am struck by the similarities of our experiences, even though mine was more than 20 years ago. I too remember walking up Capitol Hill in a new suit, copies of a resume abridged from my CV in hand, wondering if anyone would take me in. Through a mutual friend I connected with Kerry Knott, chief of staff to Representative Dick Armey, Republican of Texas, and he gave me the opportunity to serve in Armey's leadership office.

Armey, Knott, and the staff they led were smack in the vanguard of the Republican Revolution. The prior year, thenGOP Conference Chair Armey and his team had worked with rank-and-file members to develop the policy planks of the Contract with America. When the Republicans took over the House in 1995, Armey became Majority Leader. Armey and his staff, enjoying a remarkable delegation of power from Speaker Newt Gingrich, orchestrated the successful passage through the House of nine of the 10 planks in the Contract during the first 100 days of the 104th Congress. These were very heady days.

In the second half of that congress, however, the Republican Revolution began to falter. Indeed, the week I reported to work, in November of 1995 , coincided with the initial government shutdown in the running feud that congressional Republicans would wage with the Clinton administration over government spending that winter. The resulting turbulence broke the GOP's momentum and generated considerable unrest in the Majority.
Understanding the difficulties encountered by the GOP Majority, and how the leadership team could best respond to them, became the focus of my fellowship year. Working with Knott and a small team from the Speaker's office, we assessed a range of questions that were bedeviling the House Republicans. How could the Speaker, Majority Leader, and the rest of the leadership team stay focused on the big picture and avoid getting bogged down in tactical details? How should the leadership balance its engagement with committees, on the one hand, and the task forces it had set up to develop policy outside of them, on the other? How could the Majority learn from its mistakes in the budget showdown with the Clinton administration? More broadly, what enabled the House Republicans to work together so productively in the run up to the election of 1994 and during the burst of legislation in the first part of 1995 , only to have things fall apart later in the year? How could the leaders and rank-and-file get back in sync and on track?

In grappling with these questions, we had the opportunity to engage not only with the GOP leadership and staff but also the committee chairs, task force leaders, and back benchers. We got an earful and learned from all sides. Much of what we learned was consistent with what have since become the standard accounts of that era, which argue that the House GOP never fully resolved the institutional tensions embodied in its ambitious agenda and the burdens of responsibility facing a new majority, especially one whose members had no experience of governing.

However, having witnessed from the inside the efforts of the leadership and rank-and-file to recover the shared sense of purpose they had enjoyed in the run up to the 1994 election and the first 100 days, I can speak to another, less reported side of the story: they did not shy away from asking hard questions of each other, confronting their own missteps, and thinking creatively about how to regain their footing. As rocky as the ground was, they eventually were able to do so, and thereby left a major imprint on public policy. ${ }^{1}$

For my part, the fellowship put my career on a new trajectory. During it, I discovered that I liked - and had a knack foranalyzing how groups were functioning, what they could do better, how they could draw out lessons from past events and develop better plans for the future. I began reading new bodies of literature from business leaders, management consultants, and military strategists. Given the Speaker's interest in their 
ideas, we often had the opportunity to meet and consult with these experts as we were developing our assessments. I had never experienced anything quite like this. I also discovered that I enjoyed working as a member of a high-performing team. It was energizing to start each morning in Armey's leadership staff meeting, hear what the plans were for the day,
In 2005, I accepted an offer to join the Bridgespan Group, a consultancy that works with nonprofits and state and local government agencies focused on breaking inter-generational cycles of poverty. My feel for federal budgeting turned out to be especially important in the wake of the Great Recession, when steep federal cuts ripped down through state and

\section{... I can speak to another, less reported side of the story: they did not shy away from asking hard questions of each other, confronting their own missteps, and thinking creatively about how to regain their footing. As rocky as the ground was, they eventually were able to do so, and thereby left a major imprint on public policy.}

and consider how my own work could add to the mix. Armey and Knott had recruited a very talented staff team that had a well-deserved reputation for effectiveness. ${ }^{2}$ Joining it raised my game. At the end of my fellowship, I began looking for career paths that would enable me to replicate this unique work environment. I applied to several top-tier management consulting firms, which I sensed could provide such opportunities, and had the good fortune of getting an offer to join the Boston Consulting Group (BCG) in 1997.

After changing lanes from academic political science to business consulting, I had a lot of catching up to do to master the financial and market analyses which had by then had become second nature for my peers, the vast majority of whom had been recruited from leading MBA programs. That said, I discovered that my fellowship gave me a leg up. My peers' professional experience and business school training inclined many of them to see government as a black box that more or less randomly generated new rules and incentives for the business firms we were advising. From my time on the Hill, however, I had a curiosity about and grounded understanding of what was happening within that black box. I was able to bring this unique perspective to bear in a number of client engagements that I worked on over the years in the health care, industrial goods, telecommunications, and energy sectors.

At one point, an opportunity came up to advise the CEO of one of our largest industrial goods clients who been confirmed as a cabinet secretary. He wanted our help in overhauling and reorienting the department he led. BCG had not yet worked with the federal government, and most of my business-minded peers saw this assignment as something of an oddity. I jumped at the chance to do it. We supported the leaders of the department over the next two years on a wide range of strategic, organizational, and budget questions. We also began advising other cabinet and sub-cabinet appointees in other departments. I drew upon the perspectives and personal network I had cultivated during my congressional fellowship as I advised leaders who in many cases were new to government and a bit bewildered by the workings of their own agency and the executive branch, let alone the Congress that would be funding and overseeing their work. municipal budgets, straining the government funding that was the largest source of support for many of our clients. Recognizing that nonprofit leaders at the grassroots were feeling the pain of this retrenchment, I started writing and blogging to help them make sense of what was happening, why, and what they could do about it (Stid and Seldon 2012; Stid 2012a).

Another focus of my client work and writing during this period was backing a growing effort, reflected in several Obama administration initiatives, to shift more of the federal budget to evidence-based policies and programs (Stid et al. 2012; Stid 2013). I gained a reputation as a nag among the nonprofit leaders and advocates working toward this goal because of my refrain that we had to engage members of Congress and their staff if the effort was ever going to have staying power; executive branch action on its own could only do so much. This was patently obvious to the few of us in the policy network who had Hill experience, and in due course the movement has been able to gain traction in Congress. ${ }^{3}$

During these years I grew increasingly discouraged by the ways in which the federal policies and funding flows I was helping my clients navigate were biased toward the status quo in what I termed the "social services industrial complex" (Stid 2012b). The steep and across-the-board spending caps embodied in the sequestration stemming from the Budget Control Act of 2011 were Exhibit A in this regard. Normally a defender of Congress and its role in our system, I was more hard-pressed to say that impasses in Washington usually worked themselves out in a satisfactory way.

Against this backdrop, in 2013 I got an offer I couldn't refuse. Larry Kramer, the new president of the Hewlett Foundation, was interested in responding to the intertwined problems of polarization, hyper-partisanship, and gridlock in Washington. Given my background in strategy, nonprofits, and Congress, he recruited me to help develop the strategy for and then lead this exploratory project.

We launched the Madison Initiative in March of 2014 with a three-year, \$5 million grant making budget. Most philanthropy meant to support democracy in the United States is focused on improving the "inputs" to government: for example, citizen engagement, voter participation, nonprofit media, campaign 
finance and electoral reforms. For our part, we wanted to determine whether a foundation could help improve the institutions of government. In particular, could we help foster conditions in which Congress and its members can deliberate, negotiate, and compromise in ways that more Americans support? essential role that Congress, with all of its warts and shortcomings, plays in our system of government. It also taught me that the well-being of this great and maddening institution is something in which we all have a stake as citizens. For that, I will always be grateful. .

\section{Most philanthropy meant to support democracy in the United States is focused on improving the "inputs" to government: for example, citizen engagement, voter participation, nonprofit media, campaign finance and electoral reforms. For our part, we wanted to determine whether a foundation could help improve the institutions of government.}

Our premise is that we live in a big, diverse country encompassing conflicting beliefs, ideas, and agendas. That is not a bug but a feature, as we say out here in Silicon Valley. But the Madisonian system also presumes that we have functional institutions in which these diverse viewpoints can be fully represented, weighed, and balanced, if not fully reconciled, so that we can reach collective decisions about how to proceed as a nation. As I came to fully appreciate during my fellowship year, for better or worse, it is ultimately in Congress that this process of representation and policy settlement needs to occur, hence our institutional focus.

The 2016 presidential campaign and its aftermath demonstrate we have our work cut out for us. But they also highlight how important the work is-and philanthropic institutions like ours are well positioned to tackle riskier, longer term challenges. Just after the 2016 election, the Foundation's board renewed the Madison Initiative for another five years. During this period we will make an additional \$10o million in grants to support nonprofit organizations, advocates, and scholars seeking to understand and uphold the values, norms, and institutions underpinning our liberal democracy. Our remit in the second phase of our work will thus be a bit broader, but improving the institutional health of Congress so that it can fully carry out its constitutional responsibilities remains one of our central objectives.

So things have come full circle. In the back half of my career, I am once again working to assess and improve how Congress works. This probably is not an accident. Like the other fellows sharing their perspectives in this symposium, the fellowship left me with a realistic appreciation of the

\section{NOTES}

1. As the late Randall Strahan has documented (2007), by 1998, 16 bills generated by the Contract or reflecting its recommendations had become law, including major legislation reforming welfare, reducing taxes, and supporting ballistic missile defense. In the year following the shutdowns of 1995-1996, President Clinton concurred in a State of the Union address that "the era of big government is over," and Congress and the White House had agreed on the Balanced Budget Act.

2. This reputation would be subsequently validated as different Armey staff went on to take up top level posts elsewhere in Washington, including Chairman of the Republican National Committee, White House Director of Legislative Affairs; Deputy National Security Advisor; Assistant Secretary of the Treasury; chief of staff at Treasury and State; and head of government relations at Microsoft, Verizon, and the Heritage Foundation.

3. See, for example, the Commission on Evidence-Based Policy (www.cep.org), established by the bipartisan Evidence-Based Policymaking Commission Act of 2016 (P.L. 114-140). I first crossed paths with Ron Haskins of the Brookings Institution, one of the co-chairs of the Commission, and an ally in the push to engage Congress on these issues, back in the 104th Congress when he was the GOP staff lead on the Ways and Means Committee working on welfare reform.

\section{REFERENCES}

Stid, Daniel. 2012a. "Cliff Notes for Government, Nonprofits, and Philanthropy." Bridgespan Group. October 24. Available at: https://www.bridgespan.org/ insights/blog/government-and-philanthropy/cliff-notes-for-government,nonprofits,-and-philan

. 2012b. "Dismantling the Social Services Industrial Complex." Washington Post. April 25.

. 2013. "Pay for Success is Not a Panacea." Community Development Investment Review April: 13-18.

Stid, Daniel, and Willa Seldon. 2012. "Five Ways to Navigate the Fiscal Crisis." Stanford Social Innovation Review Winter: 37-41.

Stid, Daniel, Jeff Bradach, Jolie Glaser, and Stephanie Sud. 2012. "How is Investing in 'What Works' Working?" Bridgespan Group White Paper. November 1.

Strahan, Randall. 2007. Leading Representatives: The Agency of Leaders in the Politics of the US House. Baltimore: Johns Hopkins University Press. 


\section{APSA OJfers Iree}

Digital Publications

To Mlembers

The Member Bookshelf is a benefit available exclusively to APSA members. Over the years, APSA has created and collaborated on a broad variety of publications about the discipline. Now the association is unveiling a constantly growing library of digital versions of these publications for members to read for free!

Go to www.apsanet.org/memberbookshelf to login and read today!
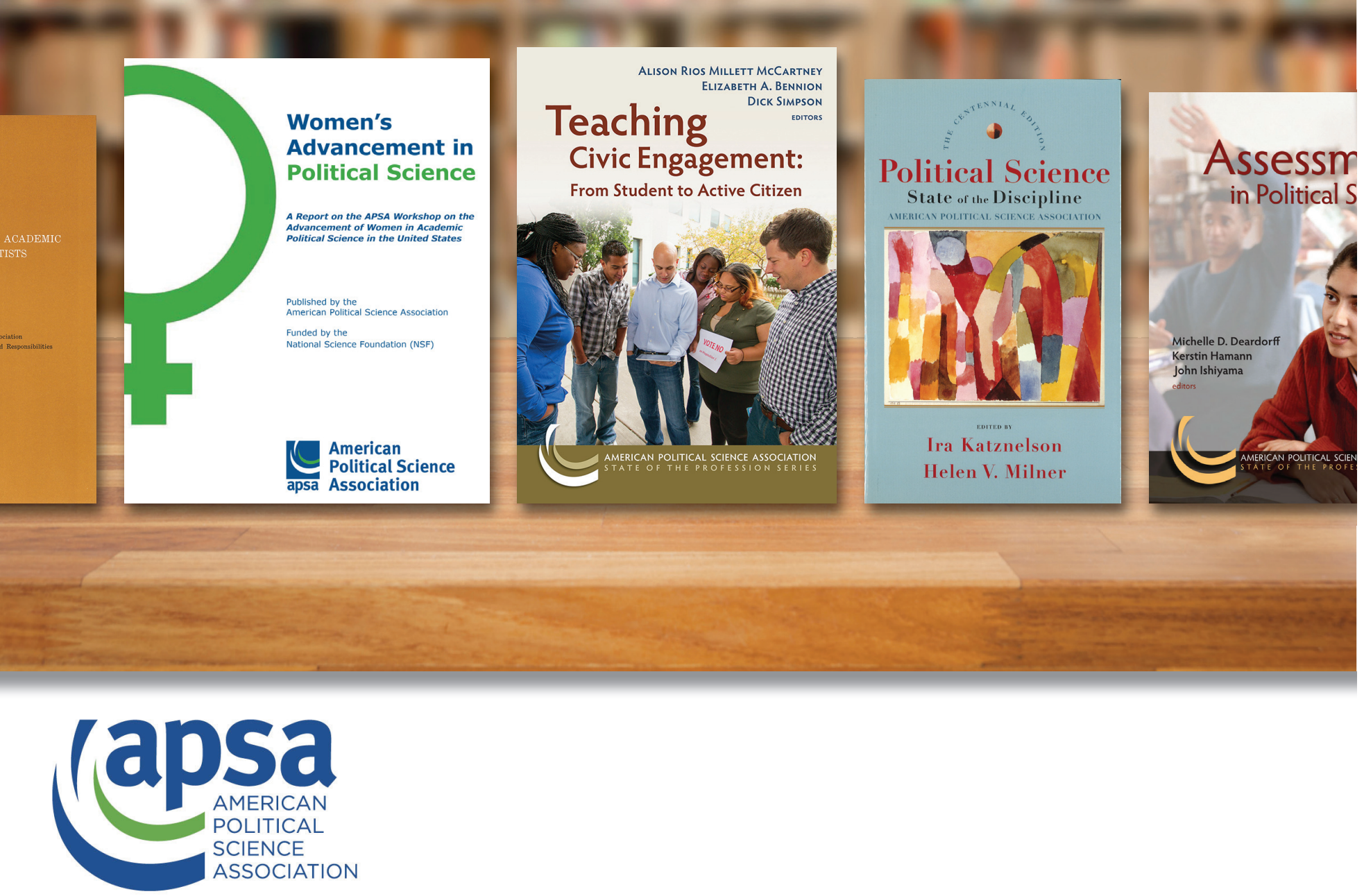